\title{
DRYING KINETICS OF NIGER SEEDS
}

Doi:http://dx.doi.org/10.1590/1809-4430-Eng.Agric.v37n4p727-738/2017

\section{FERNANDA P. DA SILVA ${ }^{*}$, VALDINEY C. SIQUEIRA ${ }^{2}$, GUILHERME A. QUINZANI ${ }^{2}$, ELTON A. S. MARTINS ${ }^{2}$, ANDRÉ L. D. GONELI ${ }^{2}$}

${ }^{1 *}$ Corresponding author. Universidade Federal da Grande Dourados/ Dourados - MS, Brasil.

E-mail: fehpimentel@ hotmail.com

\begin{abstract}
The objectives of this study were to describe the process of drying niger seeds through the fitting of different mathematical models to the experimental drying data, to select the best model that represents the phenomenon, and to determine the diffusion coefficients and thermodynamic properties of the product. Seeds with an initial moisture content of 0.42 (d.b) were collected and dried at $40^{\circ}, 50^{\circ}, 60^{\circ}, 70^{\circ}$, and $80^{\circ} \mathrm{C}$ in a fixed bed experimental dryer. After drying, different mathematical models were fitted to determine the diffusion coefficient by applying liquid diffusion theory, which allowed for calculation of the energy activation, enthalpy, entropy, and Gibbs free energy values. The Page model was selected to represent the drying process of niger seed drying, as it is a traditional and simple model. The effective diffusion coefficient increased as the temperature increased. The activation energy for liquid diffusion at the temperature range of $40^{\circ} \mathrm{C}$ to $80^{\circ} \mathrm{C}$ was $46.83 \mathrm{~kJ} \mathrm{~mol}^{-1}$. The enthalpy and entropy specific values decreased as the drying air temperature increased. The Gibbs free energy values also increased as the drying air temperature increased.
\end{abstract}

KEYWORDS: activation energy, effective diffusion coefficient, Guizotia abyssinica Cass, mathematical models.

\section{INTRODUCTION}

Niger (Guizotia abyssinica Cass) is an annual erect shrub that is mainly cultivated because of the high oil content of the seeds. Some countries that use large amounts of vegetable oil, such as Ethiopia and India, are major producers of this crop, and cultivate it in conventional agricultural systems.

Oleaginous plants have been introduced as winter crops in Brazil, especially in the CentralWest region of the country, in areas previously under fallow; thus, niger ranging from $30 \%$ to $40 \%$ in oil content (Ghane et al., 2012; Ramadan 2012) has a great potential to be cultivated in this region (Gordin et al., 2012). The oil from niger seeds can be used for several industrial purposes, such as making soaps, paints, and lubricants, and can also be used as raw material in biodiesel production.

One of the main postharvest steps is to dry the agricultural products. Drying can be defined as a process that involves simultaneous energy and mass transfer between the product and the drying air. Drying also consists of the removal of excess water contained in the seed by evaporation, which is generally achieved by forced convection of warm air.

Drying rates of agricultural products are defined by a thin layer drying tests, which is achieved by recording mass losses that occur in a sample during water removal.

Several models have been fitted in an attempt to describe the drying process of agricultural products. Such models include the Midilli, Page, Thompson, Verma, Henderson and Pabis, logarithmic, two-term, two-term exponential, Newton, Wang and Singh, diffusion approximation, and Valcam models (Mohapatra \& Rao, 2005; Kashaninejad et al., 2007; Goneli et al., 2009; Corrêa et al., 2010; Resende et al., 2011; Prates et al., 2012; Reis et al., 2012; Siqueira et al., 2012a; Siqueira et al., 2012b; Isquierdo et al., 2013; Santos et al., 2013).

\footnotetext{
${ }^{2}$ Universidade Federal da Grande Dourados/ Dourados - MS, Brasil 
Activation energy is defined as the least amount of energy required for water molecules to surpass energy barriers during migration inside of a product with consideration of diffusion mechanisms. During drying, low activation energy corresponds to a fast speed of water removal from the product (Resende et al., 2011).

Liquid diffusion theory assumes that there is no influence from capillarity, ignores the effects of energy and mass transfer from one body to another, and also considers that the bodies will reach instantaneous thermal equilibrium with the air (Faria et al., 2012). The effective diffusion coefficient describes the speed of water exit from the seed. Diffusivity varies according to the drying conditions, but it is not intrinsic to the material, and is generally referred to as effective diffusivity (Oliveira et al., 2006).

Specific enthalpy, specific entropy, and Gibbs free energy are among the thermodynamic parameters analyzed during the drying process of agricultural products. These parameters have been studied in several crops (Jideani \& Mpotokwana, 2009; Corrêa et al., 2010; Oliveira et al., 2013; Oliveira et al., 2014a; Oliveira et al., 2014b).

The drying of agricultural products is a process used to assure their quality and storability. Considering that mathematical modeling is a means to represent the product drying process, it can contribute to its description. The objectives of the present study were to describe the drying process of niger seeds by fitting different mathematical models to the drying experimental data, to select the best model that represents the phenomenon, and to determine the diffusion coefficient and thermodynamic properties of the product.

\section{MATERIAL AND METHODS}

This study was conducted at the Laboratory of Physical Properties of Agricultural Products and at the Laboratory of Preprocessing and Storage of Agricultural Products of the Federal University of Grande Dourados (Universidade Federal da Grande Dourados - UFGD). To conduct the experiment, niger (Guizotia abyssinica Cass) seeds were cultivated in the UFGD experimental area, located in Dourados, Mato Grosso do Sul, Brazil.

The capitula were manually harvested and threshed. Next, seeds with a moisture content of approximately $0.42 \mathrm{~d}$.b were sent to the laboratory where they were subjected to drying tests.

The niger seeds were dried with forced air flow utilizing a fixed bed experimental dryer regulated and maintained at $40^{\circ}, 50^{\circ}, 60^{\circ}, 70^{\circ}$, and $80^{\circ} \mathrm{C}$. During the drying process, four trays with a perforated bottom containing $0.01 \mathrm{~kg}$ of sample each were weighed at the beginning and during drying until the process was stopped. The drying process was concluded when the moisture content of the product was equal to $0.086 \pm 0.5$ (d.b).

The air temperature during drying was monitored using a thermometer allocated inside of the dryer. The relative humidity at that place was obtained by applying the basic principles of psychrometrics. The external environmental conditions were monitored using a psychrometer along with the GRAPSI computational program. The speed of the drying air, which was monitored with using an anemometer with rotating blades, was maintained at approximately $0.85 \mathrm{~m} \mathrm{~s}^{-1}$.

To study the kinetics of niger seed drying, the moisture ratio of the product was determined for each drying condition (Equation 1):

$$
\mathrm{RX}=\frac{\mathrm{X}-\mathrm{X}_{\mathrm{e}}}{\mathrm{X}_{\mathrm{i}}-\mathrm{X}_{\mathrm{e}}}
$$

where,

$\mathrm{RX}$ - moisture ratio of the product, non-dimensional;

$\mathrm{X}$ - moisture content of the product at a specific time point, dry basis (d.b);

$\mathrm{X}_{\mathrm{i}}-$ initial moisture content of the product, d.b, and 
$\mathrm{X}_{\mathrm{e}}$ - equilibrium moisture content of the product, d.b.

The equilibrium moisture content of the seeds was obtained experimentally. The product was exposed to the same drying temperature until its mass was considered constant during three consecutive weightings of 60 minutes.

The obtained experimental drying data were fitted using mathematical models that are frequently utilized to represent the drying of agricultural products, as shown in Table 1.

TABLE 1. Mathematical models used to predict the drying of agricultural products.

\begin{tabular}{ll}
\hline Model designation & Model \\
$\mathrm{RX}=1+\mathrm{a} t+\mathrm{b} \mathrm{t}^{2}$ & Wang and Singh \\
$\mathrm{RX}=\exp \frac{-\mathrm{a}-\left(\mathrm{a}^{2}+4 \mathrm{bt}\right)^{0.5}}{2 \mathrm{~b}}$ & Thompson \\
$\mathrm{RX}=\exp \left(-\mathrm{k} \mathrm{t}^{\mathrm{n}}\right)$ & Page \\
$\mathrm{RX}=\mathrm{a} \exp (-\mathrm{kt})+\mathrm{c}$ & Logarithmic \\
$\mathrm{RX}=\mathrm{a} \exp (-\mathrm{kt})$ & Henderson and Pabis \\
$\mathrm{RX}=\mathrm{a} \exp (-\mathrm{k} \mathrm{t})+(1-\mathrm{a}) \exp (-\mathrm{k} \mathrm{b} \mathrm{t})$ & Diffusion approximation \\
$\mathrm{RX}=\mathrm{a} \exp \left(-\mathrm{k}_{0} \mathrm{t}\right)+\mathrm{b} \exp \left(-\mathrm{k}_{1} \mathrm{t}\right)$ & Two-term \\
$\mathrm{RX}=\mathrm{a}+\mathrm{b} \mathrm{t}+\mathrm{c} \mathrm{t} \mathrm{t}^{1.5}+\mathrm{d} \mathrm{t}^{2}$ & Valcam
\end{tabular}

$\mathrm{t}$ - drying time, $\mathrm{h} ; \mathrm{k}, \mathrm{k}_{0}, \mathrm{k}_{1}$ - drying constants, $\mathrm{h}^{-1}$, and a, b, c, n - model coefficients.

The effective diffusion coefficient of niger seeds was calculated for the different drying conditions using [eq. (10)], which is based on liquid diffusion theory. It represents an analytical solution for Fick's second law, considering the geometric shape of the product as spherical with eight terms for approximation.

The effective diffusion model for the spherical geometric form, considering a seed mean equivalent radius of to $1.1365 \mathrm{~mm}$, was obtained by non-linear regression (Equation 10).

$$
\mathrm{RX}=\frac{\mathrm{X}-\mathrm{X}_{\mathrm{e}}}{\mathrm{X}_{\mathrm{i}}-\mathrm{X}_{\mathrm{e}}}=\frac{6}{\pi^{2}} \sum_{\mathrm{n}_{\mathrm{t}}=1}^{\infty} \frac{1}{\mathrm{n}_{\mathrm{t}}{ }^{2}} \exp \left[\frac{\mathrm{n}_{\mathrm{t}}{ }^{2} \pi^{2} \mathrm{D}_{\mathrm{i}} \mathrm{t}}{9}\left(\frac{3}{\mathrm{R}_{\mathrm{e}}}\right)^{2}\right]
$$

where,

$\mathrm{D}_{\mathrm{i}}$ - liquid diffusion coefficient, $\mathrm{m}^{2} \mathrm{~s}^{-1}$

$\mathrm{R}_{\mathrm{e}}$ - sphere equivalent radius, $\mathrm{m}$, and

$\mathrm{n}$ - number of terms.

To calculate the sphere equivalent radius used in the effective diffusion model (Equation 10), the three orthogonal axes of the niger seeds were measured, which included the length (a), width (b), and thickness (c). A total of 50 seeds were randomly chosen and measured with the aid of a digital micrometer with a resolution of $0.0001 \mathrm{~mm}$.

The volume of each seed was calculated based on the perpendicular diameters using [eq. (11)]:

$$
\mathrm{V}_{\mathrm{g}}=\pi\left(\frac{\mathrm{a} \mathrm{b} \mathrm{c}}{6}\right)
$$

where,

$\mathrm{V}_{\mathrm{g}}$ : seed volume, $\mathrm{mm}^{3}$; 
a: length, mm;

b: width, mm; and

c: thickness, mm.

The Arrhenius equation was applied to evaluate the effect of temperature on the effective diffusion coefficient:

$$
\mathrm{D}_{\mathrm{i}}=\mathrm{D}_{0} \exp \left(\frac{\mathrm{E}_{\mathrm{a}}}{\mathrm{R} \mathrm{T}_{\mathrm{a}}}\right)
$$

where,

$\mathrm{D}_{\mathrm{o}}$ - pre-exponential factor,

$\mathrm{R}$ - universal gas constant, $8.314 \mathrm{kJkmol}^{-1} \mathrm{~K}^{-1}$,

$\mathrm{T}_{\mathrm{a}}$ - temperature, $\mathrm{K}$, and

$\mathrm{E}_{\mathrm{a}}$ - activation energy, $\mathrm{kJ}^{\mathrm{mol}}{ }^{-1}$.

The thermodynamic properties of the niger seed drying process (Equations 13, 14 and 15) were obtained using the method described by Jideani \& Mpotokwana (2009):

$$
\begin{aligned}
& \mathrm{h}=\mathrm{E}_{\mathrm{a}}-\mathrm{RT} \\
& \mathrm{s}=\mathrm{R}\left(\ln \mathrm{D}_{0}-\ln \frac{\mathrm{k}_{\mathrm{B}}}{\mathrm{h}_{\mathrm{p}}}-\ln \mathrm{T}\right) \\
& \mathrm{G}=\mathrm{h}-\mathrm{T}_{\mathrm{a}} \mathrm{S}
\end{aligned}
$$

where,

$$
\begin{aligned}
& \mathrm{h} \text { - enthalpy, } \mathrm{J} \mathrm{mol}^{-1} ; \\
& \mathrm{s} \text { - entropy, } \mathrm{J} \mathrm{mol}^{-1} ; \\
& \mathrm{G} \text { - Gibbs free energy, } \mathrm{J} \mathrm{mol}^{-1} ; \\
& \mathrm{k}_{\mathrm{B}} \text { - Boltzmann constant, } 1.38 \times 10^{-23} \mathrm{~J} \mathrm{~K}^{-1} \text {, and } \\
& \mathrm{h}_{\mathrm{p}} \text { - Planck constant, } 6.626 \times 10^{-34} \mathrm{~J} \mathrm{~s}^{-1} \text {. }
\end{aligned}
$$

The experimental drying kinetics data were subjected to regression analysis and selection of the appropriate model to express the relationship among the studied variables.

The STATISTICA 7.0. was used to fit the mathematical models to the experimental data. To analyze the fit of each model, the magnitudes of the coefficient of determination of the relative mean error, standard deviation of the estimate, and distribution of the residuals were considered. The values of the relative mean error $(\mathrm{P})$ and the standard deviation of the estimate (SE) were calculated as described in eqs 16 and 17, respectively:

$$
\begin{aligned}
& \mathrm{P}=\frac{100}{\mathrm{n}} \sum\left(\frac{|\mathrm{Y}-\hat{\mathrm{Y}}|}{\mathrm{Y}}\right) \\
& \mathrm{SE}=\sqrt{\frac{\sum(\mathrm{Y}-\hat{\mathrm{Y}})^{2}}{\mathrm{DF}}}
\end{aligned}
$$

where, 
Y - observed experimental value;

$\hat{Y}$ - value estimated by the model;

$\mathrm{N}$ - number of experimental observations, and

$\mathrm{DF}$ - degrees of freedom of the model (number of observations minus the number of model parameters).

\section{RESULTS AND DISCUSSION}

The standard deviation of the estimate (SE), relative mean error $(\mathrm{P})$ and coefficient of determination $\left(\mathrm{R}^{2}\right)$ are presented in Table 2. These parameters were used in the comparisons for the eight models, which were fit according to the experimental moisture ratio data obtained during the drying of niger seeds at different temperatures.

TABLE 2. Statistical parameters obtained for the eight models used in the drying of niger seeds.

\begin{tabular}{|c|c|c|c|c|c|c|c|c|c|c|c|c|c|c|c|}
\hline \multirow{2}{*}{ Models } & \multicolumn{3}{|c|}{$40^{\circ} \mathrm{C}$} & \multicolumn{3}{|c|}{$50^{\circ} \mathrm{C}$} & \multicolumn{3}{|c|}{$60^{\circ} \mathrm{C}$} & \multicolumn{3}{|c|}{$70^{\circ} \mathrm{C}$} & \multicolumn{3}{|c|}{$80^{\circ} \mathrm{C}$} \\
\hline & SE & $\mathrm{P}$ & $\mathrm{R}^{2}$ & SE & $\mathrm{P}$ & $\mathrm{R}^{2}$ & SE & $\mathrm{P}$ & $\mathrm{R}^{2}$ & SE & $P$ & $\mathrm{R}^{2}$ & SE & $\mathrm{P}$ & $\mathrm{R}^{2}$ \\
\hline (2) & 0.079 & 32.08 & 0.94 & 062 & 14.84 & 0.95 & 046 & 13.66 & 0.98 & 0.074 & 14.71 & 0.94 & 0.051 & 13.43 & 0.97 \\
\hline (3) & 0.013 & 5.47 & 0.99 & 0.010 & 1.93 & 0.99 & 0.005 & 1.38 & 0.99 & 0.019 & 4.34 & 0.99 & 0.037 & 5.37 & 0.99 \\
\hline (4) & 0.006 & 1.77 & 0.99 & 0.003 & 0.58 & 0.99 & 0.009 & 2.49 & 0.99 & 0.013 & 2.52 & 0.99 & 0.040 & 6.37 & 0.98 \\
\hline (5) & 0.022 & 6.96 & 0.99 & 0.020 & 4.09 & 0.99 & 0.010 & 2.43 & 0.99 & 0.038 & 6.89 & 0.99 & 0.037 & 5.41 & 0.99 \\
\hline ( & 030 & 12.54 & 0.99 & 0.037 & 9.07 & 0.98 & 0.026 & 8.96 & 0.99 & 0.052 & 10.47 & 0.97 & 0.047 & 11.82 & 0.98 \\
\hline (7) & 0.006 & 2.97 & 0.99 & 0.008 & 1.83 & 0.99 & 0.006 & 1.49 & 0.99 & 0.009 & 2.05 & 0.99 & 0.037 & 5.15 & 0.99 \\
\hline (8) & 0.007 & 2.96 & 0.99 & 0.008 & 1.77 & 0.99 & 0.006 & 1.51 & 0.99 & 0.009 & 2.05 & 0.99 & 0.041 & 5.48 & 0.99 \\
\hline (9) & 0.014 & 4.53 & 0.99 & 0.011 & 1.94 & 0.99 & 0.007 & 1.60 & 0.99 & 0.028 & 5.12 & 0.99 & 0.043 & 5.74 & 0.99 \\
\hline
\end{tabular}

The fitted models exhibited coefficient of determination values $\left(\mathrm{R}^{2}\right)$ close to 0.98 , except for the Wang and Singh model, for which only the results at a temperature of $60{ }^{\circ} \mathrm{C}$ were satisfactory. According to Madamba et al. (1996), values close to 0.98 reflect good model fit for representing the drying process. However, these authors also note that the use of the coefficient of determination $\left(\mathrm{R}^{2}\right)$ as the only criterion to select non-linear models is not a good parameter to represent the drying phenomenon. Therefore, a joint analysis including other statistical parameters was conducted.

Among the models applied to predict the niger seed drying process, the Henderson and Pabis and the Wang and Singh models exhibited relative mean error values greater than $10 \%$. According to Kashaninejad et al. (2007), the values of the relative mean error indicate the deviation of the observed values relative to the estimated curve of the model. Mohapatra \& Rao (2005) state that models with relative mean error values greater than $10 \%$ are inadequate to describe a specific phenomenon.

The Wang and Singh and Henderson and Pabis models stood out from the other models because they exhibited the highest SE values for all drying conditions. Given that this statistical parameter indicates the ability of a model to accurately describe a certain physical process, and that a smaller magnitude of SE corresponds to a higher quality of fit to the observed data (Siqueira et al., 2012a), these two models do not adequately represent the niger seed drying process.

The residual distribution trends for the models fitted to the experimental data for niger seed drying are presented in Table 3. 
TABLE 3. Residual distribution trends for the eight models fit to the experimental data for niger seed drying.

\begin{tabular}{lccccc}
\hline \multirow{2}{*}{ Mathematical models } & \multicolumn{5}{c}{ Temperature $\left({ }^{\circ} \mathrm{C}\right)$} \\
\cline { 2 - 5 } & 40 & 50 & 60 & 70 & 80 \\
\hline Wang and Singh & Biased & Biased & Biased & Biased & Random \\
Thompson & Biased & Random & Random & Random & Random \\
Page & Random & Random & Random & Random & Random \\
Logarithmic & Biased & Biased & Random & Biased & Random \\
Henderson and Pabis & Biased & Biased & Biased & Biased & Random \\
Diffusion approximation & Random & Random & Random & Random & Random \\
Two-term & Random & Random & Random & Random & Random \\
Valcam & Biased & Random & Random & Random & Random \\
\hline
\end{tabular}

Table 3 shows that the Page, diffusion approximation, and two-term models displayed a random residual distribution under all drying conditions. Thus, these three models had the best fit to the experimental data for niger seed drying.

Figures $1 \mathrm{~A}$ and $1 \mathrm{~B}$ show the distributions of the residuals (random for the Page model and biased for the Wand and Singh model) during the modeling of niger seed drying.

A.

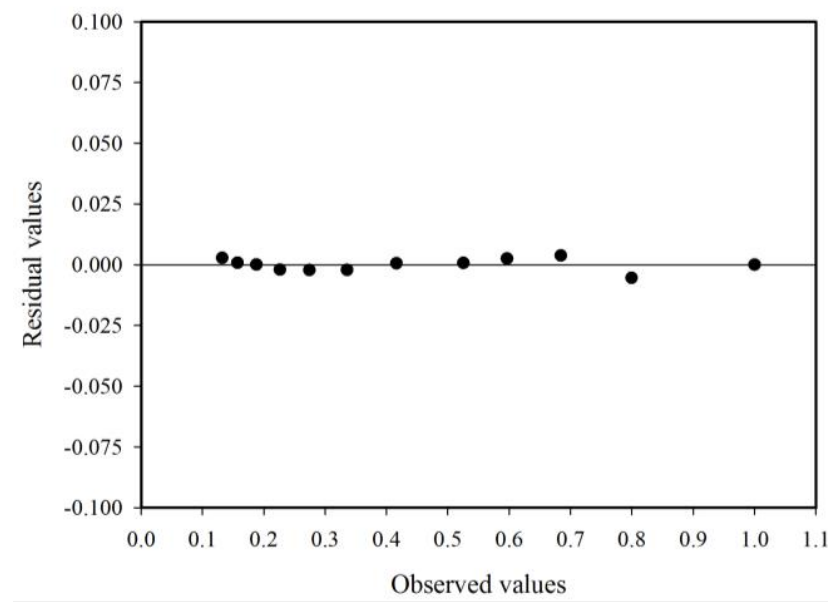

B.

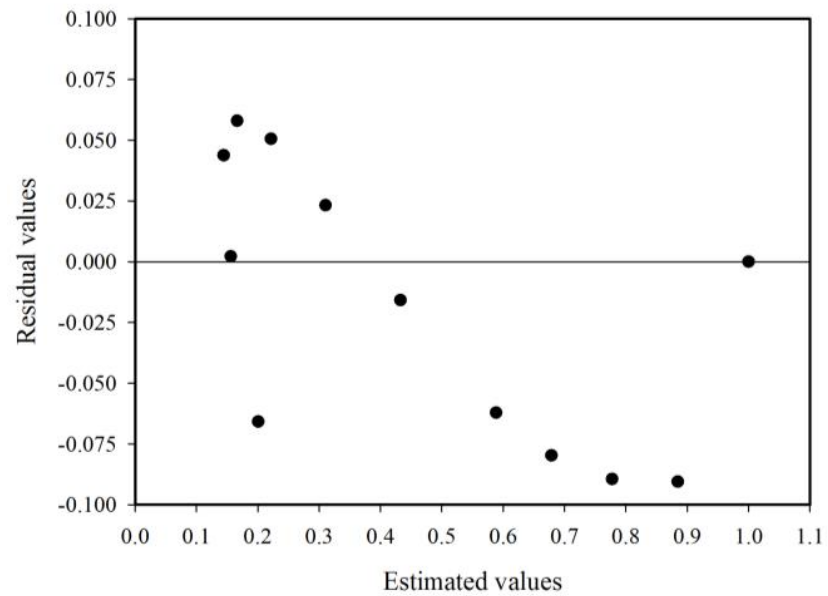

FIGURE 1. Distributions of the residuals: random for the Page model (A) and biased for the Wand and Singh model (B) during the drying process of niger seeds.

Among the three models that meet the statistical requirements and that are recommended to represent the thin-layer drying of niger seeds, the Page model is the simplest and most traditional model. The simplicity of the Page model is related to the fewer number of parameters that it requires, and its common use is related to its continued recommendation and application to represent the thin-layer drying process for various agricultural products, including jatropha fruit (Siqueira et al., 2012a), pistachio nuts (Kashaninejad et al., 2007), hulled coffee beans (Goneli et al., 2009), and cactus pear (Madureira et al., 2011).

Figure 2 presents the comparisons between the estimated and observed moisture ratio values using the Page model for all thin-layer drying air conditions for niger seeds. For all studied temperatures, the Page model provided a good fit for describing the drying kinetics for this crop. 


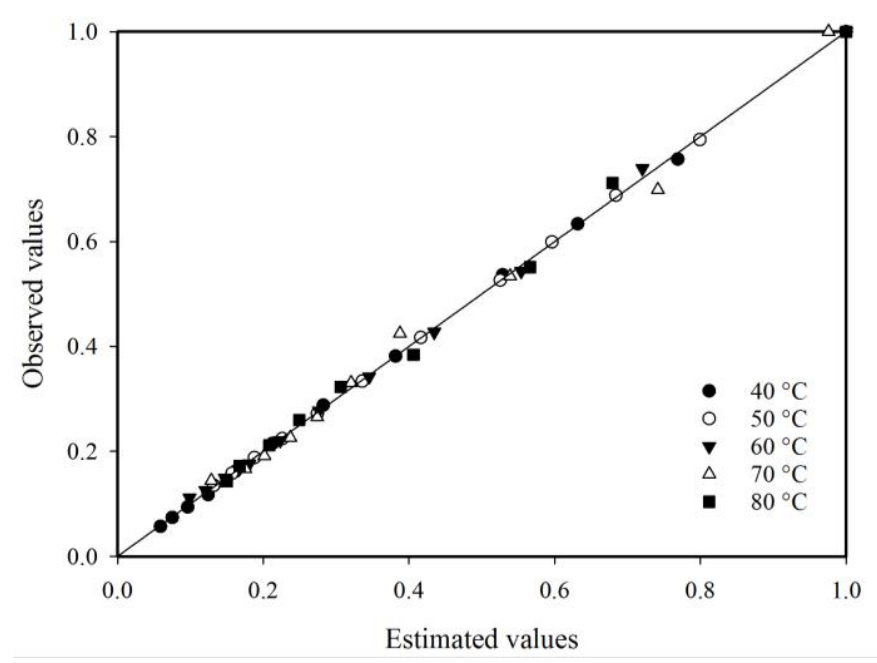

FIGURE 2. Observed and estimated moisture ratio values using the Page model for thin-layer niger seed drying under different temperatures.

The Page model showed excellent fit and fidelity with respect to the behavior of niger seed drying (Figure 3). Additionally, higher temperatures led to shorter drying times. This behavior is due to the higher rate of water removal from the product under higher temperatures because of an increased difference between the water vapor pressure of the air and the seeds. The same behavior has been observed in other studies, such as the works of Siqueira et al. (2012b) and Resende et al. (2014).

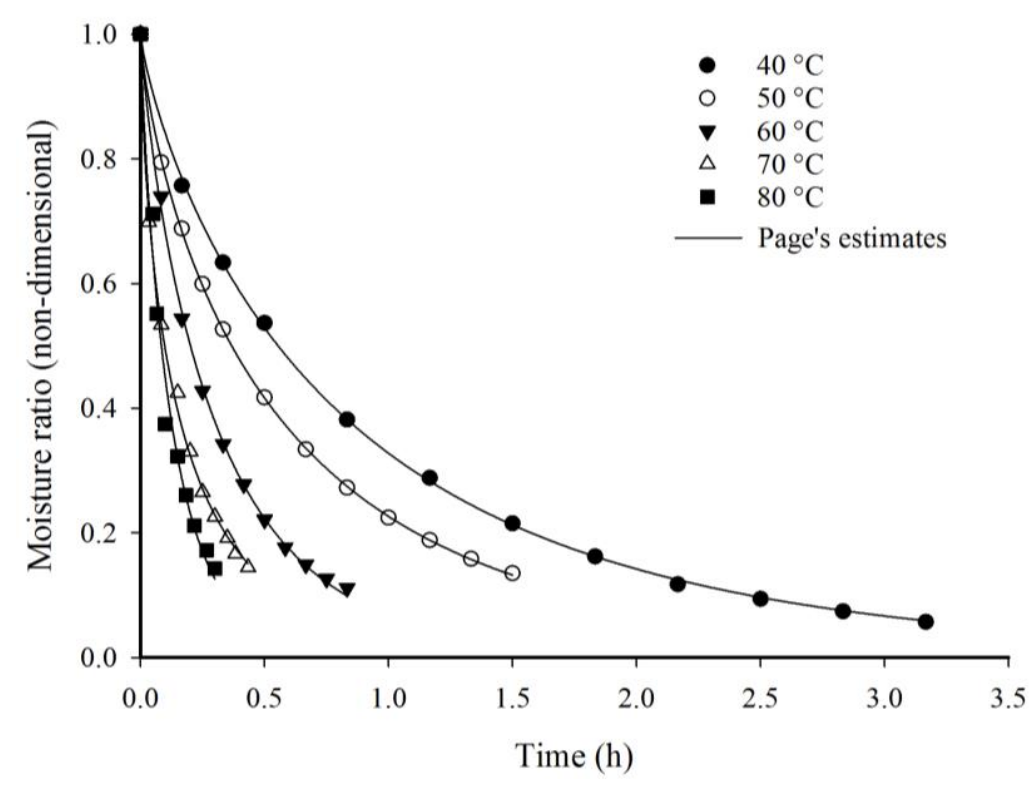

FIGURE 3. Moisture ratio values estimated by the Page model for thin-layer niger seed drying.

The decrease in the seed moisture ratio is greater at the beginning of the process for all the drying temperatures tested. As the drying process continues, the release of water from the seed occurs with greater difficulty because the water is strongly bound to the product. This causes the moisture ratio curve to display the pattern shown in Figure 3.

The parameters of the Page model fit to the experimental data for niger seed drying under different temperature conditions are presented in Table 4. 
TABLE 4. The Page model parameters for different temperatures used during niger seed drying.

\begin{tabular}{ccc}
\hline \multirow{2}{*}{ Temperature $\left({ }^{\circ} \mathrm{C}\right)$} & $\mathrm{k}$ & Parameters \\
\cline { 2 - 3 } & $\mathrm{k}$ & $\mathrm{N}$ \\
\hline 40 & 1.115661 & 0.807568 \\
50 & 1.485567 & 0.761612 \\
60 & 2.700678 & 0.848577 \\
70 & 3.323381 & 0.673447 \\
80 & 5.848469 & 0.862072 \\
\hline
\end{tabular}

The " $n$ " parameter does not display a defined behavior. However, the " $k$ " parameter increased as the drying air temperature increased. Because of its progressive increase with the increase in drying air temperature, the behavior of " $\mathrm{k}$ " can be described by [eq. (18)]:

$$
\mathrm{k}=0.113 \mathrm{x}-3.877 \quad \mathrm{R}^{2}=0.906
$$

Equation 18, used to describe the " $k$ " coefficient values of the Page model as a function of air temperature, showed a good fit, having a coefficient of determination value of 0.906 .

Using [eq. (18)] for the " $k$ " coefficient and the mean value of the " $n$ " coefficient from the Page model, the moisture content of the product for all drying air conditions tested can be estimated using [eq. (19)]:

$$
X=X_{e}+\left(X_{i}-X_{e}\right) \exp \left(-(0.113 X-3.8873) t^{0.790656}\right)
$$

where,

$\mathrm{t}$ - drying time, $\mathrm{h}$, and

$\mathrm{x}$ - drying air temperature, ${ }^{\circ} \mathrm{C}$.

The mean effective diffusion coefficient values obtained during the drying of niger seeds for different temperature conditions are presented in Table 5, considering a seed equivalent radius equal to $1.1365 \mathrm{~mm}$.

TABLE 5. Mean effective diffusion coefficient values as a function of the niger seed air drying temperature.

\begin{tabular}{cc}
\hline Temperature $\left({ }^{\circ} \mathrm{C}\right)$ & $\mathrm{D} \times 10^{-11}\left(\mathrm{~m}^{2} \mathrm{~s}^{-1}\right)$ \\
\hline 40 & 2.3273 \\
50 & 3.2761 \\
60 & 6.7006 \\
70 & 11.7050 \\
80 & 15.6915 \\
\hline
\end{tabular}

Table 5 shows that the effective diffusion coefficients increased as the temperature increased. A similar behavior was observed by Goneli et al. (2009) for the drying kinetics of hulled coffee. The authors highlighted that as the temperature increases, the water viscosity decreases. Viscosity is a measure of a fluid's resistance to flow. Variations in this property imply changes in water diffusion in the capillaries within the seed that favor the movement of this fluid inside the product.

The effective diffusion coefficient for the niger seeds under the different drying temperatures varied between $2.3273 \times 10^{-11} \mathrm{~m}^{2} \cdot \mathrm{s}^{-1}$ at $40^{\circ} \mathrm{C}$ and $15.6915 \times 10^{-11} \mathrm{~m}^{2} \cdot \mathrm{s}^{-1}$ at $80^{\circ} \mathrm{C}$. According to Madamba et al. (1996), the effective diffusion coefficient for the drying of agricultural products varies from $10^{-9}$ to $10^{-11} \mathrm{~m}^{2} \cdot \mathrm{s}^{-1}$. Therefore, the values calculated for niger seed were within the range established by that study. 
Figure 4 presents the Ln (D) values as a function of the inverse absolute temperature for the niger seeds. The decreasing linearity observed is evidence of the uniform variation in the drying rate within the studied temperature range. The slope of the Arrhenius curve represents the Ea ratio, whereas its intersection with the $y$-axis indicates the $D_{o}$ value.

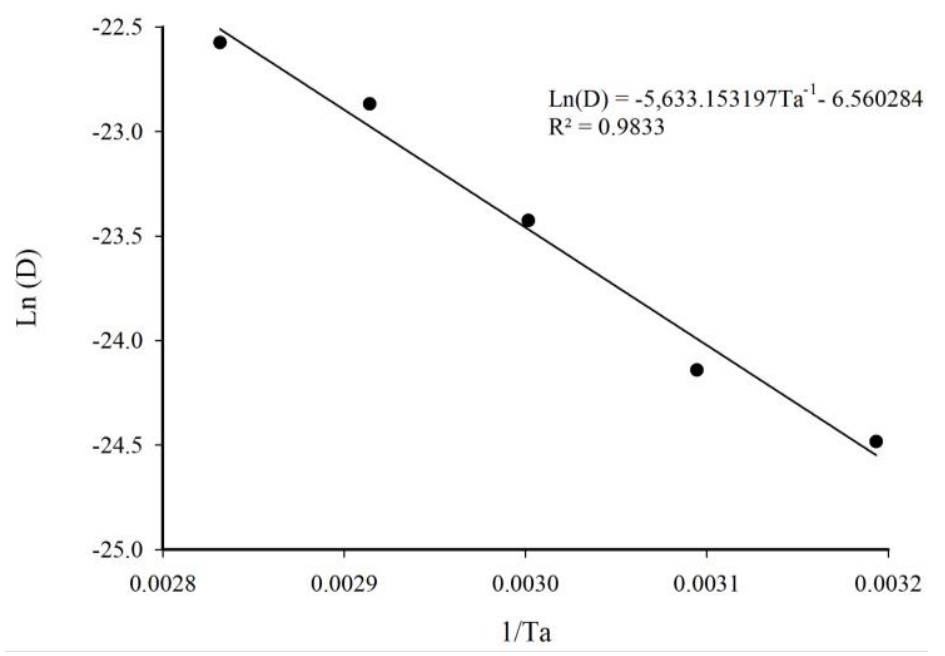

FIGURE 4. Arrhenius representation of the effective diffusion coefficient as a function of different niger seed drying temperatures.

Equation 20 presents the Arrhenius equation coefficients adjusted to the effective diffusion coefficient of niger seeds, calculated according to [eq. (12)].

$$
\mathrm{D}_{\mathrm{i}}=1.415510^{-3} \exp \left(\frac{46.834}{\mathrm{R} \mathrm{T}_{\mathrm{a}}}\right)
$$

The activation energy considering the diffusion mechanisms for the temperature range from $40^{\circ}$ to $80^{\circ} \mathrm{C}$ during niger seed drying was $46.834 \mathrm{~kJ} . \mathrm{mol}^{-1}$. This value is higher than the values observed for other oleaginous products, e.g., 24.78 and $28.47 \mathrm{~kJ} \cdot \mathrm{mol}^{-1}$ observed by Sousa et al. (2011) and Duc et al. (2011) for forage turnip and canola, respectively.

Table 6 shows the values of the thermodynamic properties specific enthalpy (h), specific entropy (s), and Gibbs free energy (G) calculated for the niger seed drying process.

TABLE 6. Thermodynamic properties of the niger seed drying process.

\begin{tabular}{cccc}
\hline $\mathrm{T}\left({ }^{\circ} \mathrm{C}\right)$ & $\mathrm{h}\left(\mathrm{kJ} \mathrm{mol}^{-1}\right)$ & $\mathrm{s}\left(\mathrm{kJ} \mathrm{mol}^{-1} \mathrm{~K}^{-1}\right)$ & $\mathrm{G}\left(\mathrm{kJ} \mathrm{mol}^{-1}\right)$ \\
\hline 40 & 44.2304 & -0.2999 & 138.1336 \\
50 & 44.1473 & -0.3001 & 141.1335 \\
60 & 44.0641 & -0.3004 & 144.1360 \\
70 & 43.9810 & -0.3006 & 147.1409 \\
80 & 43.8979 & -0.3009 & 150.1483 \\
\hline
\end{tabular}

The specific enthalpy values decreased as the drying air temperature increased. This pattern can be explained by the fact that an increase in the drying air temperature causes an increase in the partial water vapor pressure in the seed while the air water vapor pressure remains constant during the air heating process.

Thus, there is an increase in the intensity of water movement from inside the product to its surface, making faster the drying process. This behavior is associated with the effective diffusion coefficient (Table 5). 
With the increase in the drying air temperature and in the partial water vapor pressure inside the seed, the free water vaporization decreases, leading to a reduction in the enthalpy of water diffusion inside the product during drying. According to Oliveira et al. (2010), a lower enthalpy value corresponds to a lower amount of energy required to remove the water from the product.

Entropy may be associated with the attraction or repulsion of water molecules to the product components in the system and is associated with the spatial arrangement of the water-product relationship (Oliveira et al., 2015). Therefore, according to Oliveira et al. (2011), entropy characterizes or defines the level of organization or disorganization that exists in the water-product system.

The specific entropy of niger seeds decreased as the drying air temperature increased (Table 6). This pattern was similar to that observed for enthalpy, for which the observed values decreased as the temperature increased.

Corrêa et al. (2010) considered expected this behavior, as the decrease in temperature causes a decrease in the excitation of water molecules, resulting in increased organization of the waterproduct system.

Cortés et al. (2012) reported that the Gibbs free energy is attributed to the spontaneity of the thermodynamic process. The Gibbs free energy of the niger seeds presented positive values that increased as the drying air temperature increased (Table 6). A positive Gibbs free energy is characteristic of an endergonic reaction that requires energy from the product's environment for the reaction development (Corrêa et al., 2010).

\section{CONCLUSIONS}

1. The Page, diffusion approximation, and two-term models are appropriate to represent the drying process of niger seeds. The Page model was selected to represent the niger seed drying curves.

2. The effective diffusion coefficient increased as the niger seed drying air temperature increased, with values ranging from 2.3273 to $15.6915 \times 10^{-11} \mathrm{~m}^{2} \mathrm{~s}^{-1}$.

3. The drying air temperature increase caused a reduction in the specific enthalpy and entropy values. The Gibbs free energy values displayed the opposite pattern.

4. The relationship between the effective diffusion coefficient and the drying air temperature can be described using the Arrhenius equation. This equation yielded diffusion activation energy of $46.834 \mathrm{~kJ} \mathrm{~mol}^{-1}$ during the drying process of niger seeds.

\section{ACKNOWLEDGEMENTS}

The authors thank PROPP/UFGD and FUNDECT - MS for financial support during the development of this research.

\section{REFERENCES}

Corrêa PC, Oliveira GHH, Botelho FM, Goneli ALD, Carvalho FM (2010) Modelagem matemática e determinação das propriedades termodinâmicas do café (Coffea arabica L.) durante o processo de secagem. Revista Ceres 57(5):595-601. DOI:http://dx.doi.org/10.1590/S0034-737X2010000500005

Cortés FB, Betancourt A, Rojano B, López V, Arenas E (2012) Evaluación de las propriedades termodinâmicas de sorción de la uchuva (Physalis peruviana L.). Biotecnología en el Sector Agropecuario y Agroindustrial 10(1):32-41.

Duc LA, Han JW, Keum DH (2011) Thin layer drying characteristics of rapeseed (Brassica napus L.). Journal of Stored Products Research 47(1):32-38.

DOI:http://dx.doi.org/10.1016/j.jspr.2010.05.006 
Faria RQ, Teixeira IR, Devilla IA, Ascheri DPR, Resende O (2012) Cinética de secagem de sementes de crambe. Revista Brasileira de Engenharia Agrícola e Ambiental 16(5):573-583.

Ghane SG, Lokhande VH, Nikam TD (2012) Differential growth, physiological and biochemical responses of niger (Guizotia abyssinica Cass.) cultivars to water-deficit (drought) stress. Acta Physiologiae Plantarum 34:215. DOI: http://dx.doi.org/10.1007/s11738-011-0820-y

Goneli ALD, Corrêa PC, Afonso Júnior PC, Oliveira GHH (2009) Cinética de secagem dos grãos de café descascados em camada delgada. Revista Brasileira de Armazenamento 11(11):64-73.

Gordin CRB, Marques RF, Masetto TE, Scalon SPQ (2012) Germinação, biometria de sementes e morfologia de plântulas de Guizotia abyssinica Cass. Revista Brasileira de Sementes 34(4):619627.

Isquierdo EP, Borém FM, Andrade ET, Corrêa JLG, Oliveira PD, Alves GE (2013) Drying kinetics and quality of natural coffee. Transactions of the ASABE 56(3):1003-1010.

DOI:http://dx.doi.org/10.13031/trans.56.9794

Jideani VA, Mpotokwana SM (2009) Modeling of water absorption of Botswana bambara varieties using Peleg's equation. Journal of Food Engineering 92(2):182-188.

DOI:http://dx.doi.org/10.1016/j.jfoodeng.2008.10.040

Kashaninejad M, Mortazavi A, Safekordi A, Tabil LG (2007) Thin-layer drying characteristics and modeling of pistachio nuts. Journal of Food Engineering 78(1):98-108.

DOI:http://dx.doi.org/10.1016/j. jfoodeng.2005.09.007

Madamba PS, Driscoli RH, Buckle KA (1996) Thin layer drying characteristics of garlic slices. Journal of Food Engineering 29(1):75-97. DOI: http://dx.doi.org/10.1016/0260-8774(95)00062-3

Madureira IA, Figueirêdo RMF, Queiroz AJM, Filho EDS (2011) Cinética de secagem da polpa do figo-da-índia. Revista Brasileira de Produtos Agroindustriais 13(n. Especial):345-354.

Mohapatra D, Rao PS (2005) A thin layer drying model of parboiled wheat. Journal of Food Engineering 66(4):513-518. DOI: http://dx.doi.org/10.1016/j.jfoodeng.2004.04.023

Oliveira GHH, Corrêa PC, Santos ES, Treto PC, Diniz MDMS (2011) Evaluation of thermodynamic properties using GAB model to describe the desorption process of cocoa beans. International Journal of Food Science and Technology 46(10):2077-2084. DOI: http://dx.doi.org/10.1111/j.1365-2621.2011.02719

Oliveira DEC, Resende O, Campos RC, Souza KA (2014a) Propriedades termodinâmicas de sementes de Tucumã-de-Goiás (Astrocaryum huaimi Mart.). Revista Caatinga 27(3):53-62.

Oliveira GHH, Aragão DMS, Oliveira APLR, Silva MG, Gusmão ACA (2015) Modelagem e propriedades termodinâmicas na secagem de morangos. Brazilian Journal of Food Technology 18(4):314-321. DOI: http://dx.doi.org/10.1590/1981-6723.5315

Oliveira DEC, Resende O, Chaves, T.H.; Souza, A.S.; Smaniotto, T.A.S. (2014b) Propriedades termodinâmicas das sementes de pinhão-manso. Bioscience Journal 30(1):147-157. Available: http://www.biosciencejournal.com.br. Accessed: Nov 20, 2015.

Oliveira DEC, Resende O, Smaniotto TAS, Sousa KA, Campos RC (2013) Propriedades termodinâmicas de grãos de milho para diferentes teores de água de equilíbrio. Pesquisa Agropecuária Tropical 43(1):50-56.

Oliveira GHH, Corrêa PC, Araújo EF, Valente DSM, Botelho FM (2010) Desorption isotherms and thermodynamic properties of sweet corn cultivars (Zea mays L.). International Journal of Food Science \& Technology 45(3):546-554. DOI: http://dx.doi.org/10.1111/j.1365-2621.2009.02163.x

Oliveira RA, Oliveira WP, Park KJ (2006) Determinação da difusividade efetiva de raiz de chicória. Revista Engenharia Agrícola 26(1):181-189. 
Prates MFO, Reis RC, Devilla IA, Faria RQ, Lima Junior AF (2012) Cinética de secagem de folhas de Solanum lycocarpum A. St.-Hil. (fruta-de-lobo). Revista Brasileira de Plantas Medicinais 14(3):514-521. DOI: http://dx.doi.org/10.1590/S1516-05722012000300014

Ramadan MF (2012) Functional properties, nutritional value and industrial applications of niger Oilseeds (Guizotia abyssinica Cass.). Critical Reviews in Food Science Nutrition 52(1):1-8. DOI: http://dx.doi.org/10.1080/10408398.2010.486083

Reis RC, Devilla IA, Ascheri DPR, Servulo ACO, Souza ABM (2012) Cinética de secagem de folhas de manjericão (Ocimum basilicum L.) via infravermelho. Revista Brasileira de Engenharia Agrícola e Ambiental 16(12):1346-1352. DOI: http://dx.doi.org/10.1590/S141543662012001200012

Resende O, Oliveira DEC, Chaves TH, Ferreira J, Bessa V (2014) Kinetics and thermodynamic properties of the drying process of sorghum (Sorghum bicolor [L.] Moench) grains. African Journal of Agricultural Research 9(32):2453-2462. DOI: http://dx.doi.org/ 10.5897/AJAR2014.8808

Resende O, Ullmann R, Siqueira VC, Chaves TH, Ferreira LU (2011) Modelagem matemática e difusividade efetiva das sementes de pinhão-manso (Jatropha curcas L.) durante a secagem. Engenharia Agrícola 31(6):1123-1135.

Santos DC, Queiroz AJM, Figueirêdo RMF, Oliveira ENA (2013) Cinética de secagem de farinha de grãos residuais de urucum. Revista Brasileira de Engenharia Agrícola e Ambiental 17(2):223231.

Siqueira VC, Resende O, Chaves TH (2012a) Difusividade efetiva de grãos e frutos de pinhãomanso. Semina 33(Supl 1):2919-2930.

Siqueira VC, Resende O, Chaves TH (2012b) Drying kinetics of Jatrophaseeds. Revista Ceres 59(2):171-177. DOI: http://dx.doi.org/10.1590/S0034-737X2012000200004

Sousa KA, Resende O, Chaves TH, Costa LM (2011) Cinética de secagem do nabo forrageiro (Raphanus sativus L.). Revista Ciência Agronômica 42(4):883-892. 